\title{
Research on critical groundwater level under the threshold value of land subsidence in the typical region of Beijing
}

\author{
Y. Jiang ${ }^{1}$, J.-R. Liu ${ }^{2}$, Y. Luo ${ }^{2}$, Y. Yang ${ }^{2}$, F. Tian ${ }^{2}$, and K.-C. Lei ${ }^{2}$ \\ ${ }^{1}$ Beijing geology prospecting \& developing bureau, Beijing, 100195, China \\ ${ }^{2}$ Hydrogeology and Engineering Geology Team of Beijing, Beijing, 100195, China
}

Correspondence to: Y. Jiang (yuan.12.3@163.com)

Published: 12 November 2015

\begin{abstract}
Groundwater in Beijing has been excessively exploited in a long time, causing the groundwater level continued to declining and land subsidence areas expanding, which restrained the economic and social sustainable development. Long years of study show good time-space corresponding relationship between groundwater level and land subsidence. To providing scientific basis for the following land subsidence prevention and treatment, quantitative research between groundwater level and settlement is necessary. Multi-linear regression models are set up by long series factual monitoring data about layered water table and settlement in the Tianzhu monitoring station. The results show that: layered settlement is closely related to water table, water level variation and amplitude, especially the water table. Finally, according to the threshold value in the land subsidence prevention and control plan of China $(45,30,25 \mathrm{~mm})$, the minimum allowable layered water level in this region while settlement achieving the threshold value is calculated between -18.448 and $-10.082 \mathrm{~m}$. The results provide a reasonable and operable control target of groundwater level for rational adjustment of groundwater exploited horizon in the future.
\end{abstract}

\section{Introduction}

Beijing suffered successive droughts since 1999, the precipitation decreased $19 \%$ in recent 12 years. The groundwater has been over exploited in order to ensure the safety of water supply for the capital, the average groundwater depth in Beijing plain decreased from $11.9 \mathrm{~m}$ (1998) to $24.3 \mathrm{~m}$ (2012), with an average annual decline of $0.89 \mathrm{~m}$, which resulted in intensified development of ground subsidence. In the future, the contradiction between supply and demand of water resources is difficult to solve, the land subsidence will be in sustained and rapid development (Yang et al., 2010).

Years of research shows that, the main causes of land subsidence in Beijing plain is groundwater overexploitation. The characteristic of land subsidence development is closely related to the intensity and depth of groundwater exploitation. The speed and magnitude of the groundwater level change directly affect the speed and amount of ground subsidence.

\section{Correlation between land subsidence and groundwater level}

The relationship between groundwater level and land subsidence in Beijing plain has the following characteristics: on the plane, the range and distribution of land subsidence and groundwater depression are similar. The groundwater depression area has been expanding continuously from 1971, now the area is more than $1000 \mathrm{~km}^{2}$ (Fig. 1). In general, the area of land subsidence is consistent with the distribution of groundwater depression regional.

In vertical, through the comparison regional land subsidence trend, layered water level and settlement, there is a good consistency between groundwater level variety and land subsidence trend. The periodic change of the settlement rate is consistent with the seasonal fluctuation of groundwater level (Yang et al., 2013) (Fig. 2). 
Table 1. Layer water level and settlement in Tianzhu station.

\begin{tabular}{llllll}
\hline Layered water level & D3-2 & D3-3 & D3-4 & D3-5 & D3-6 \\
\hline Depth & $210-218$ & $120-146.8$ & $85.7-91.3$ & $59.3-63.4$ & $27.5-31.0$ \\
Layered settlement & F3-3 & F3-4 & F3-6 & F3-8 & F3-10 \\
Depth & $148.49-218.89$ & $117-148.49$ & $82.3-102$ & $48.5-64.5$ & $2.4-35.43$ \\
Lithology & silt & silt & $\begin{array}{l}\text { Powder } \\
\text { stick }\end{array}$ & Fine sand & silt \\
& fine sand & coarse sand sand & \\
& & & fine sand & & \\
\hline
\end{tabular}

Table 2. Results of multiple regression analysis.

\begin{tabular}{llccr}
\hline Monitoring layer & Regression equation & $R$ & $R^{2}$ & $F$ \\
\hline D3-2/F3-3 & $y=1.750 x_{1}+0.108$ & 0.933 & 0.871 & 58.727 \\
D3-3/F3-4 & $y=2.095 x_{1}+0.662 x_{2}+2.038 x_{3}+0.199$ & 0.926 & 0.858 & 52.227 \\
D3-4/F3-6 & $y=1.219 x_{1}+0.657 x_{2}+1.918 x_{3}-5.240$ & 0.942 & 0.887 & 67.900 \\
D3-5/F3-8 & $y=0.248 x_{1}+0.092 x_{2}+0.128 x_{3}-0.662$ & 0.894 & 0.800 & 34.673 \\
D3-6/F3-10 & $y=2.190 x_{1}+0.378 x_{2}+2.840 x_{3}-37.338$ & 0.510 & 0.260 & 3.044 \\
\hline
\end{tabular}

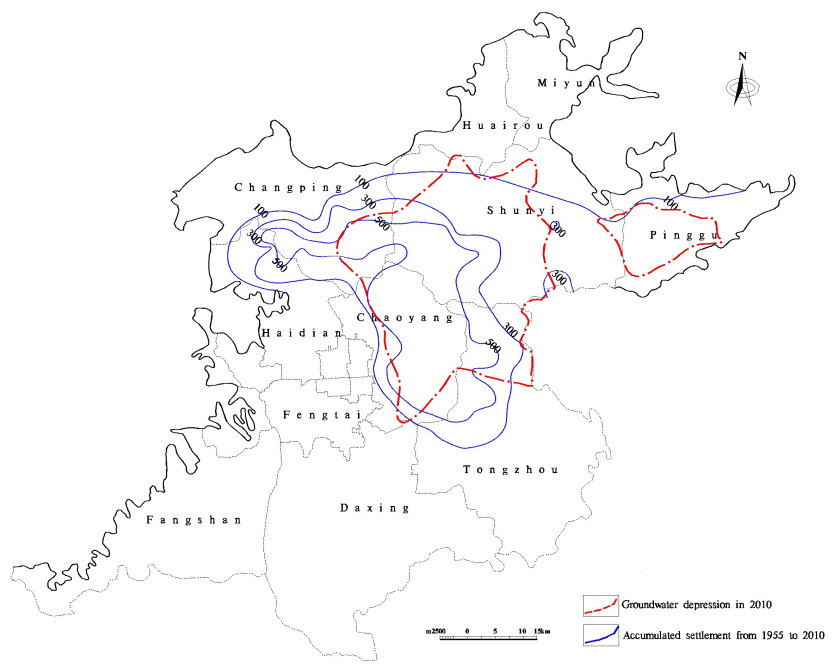

Figure 1. Groundwater depression in 2010 and accumulated settlement from 1955 to 2010 .

\section{Correlation research on water level and settlement}

According to the sediment regulation of the quaternary stratum, the underground water layer structure, exploitation utilization of groundwater and other factors, the aquifer in Beijing area can be divided into four groups: the first aquifer group, mainly phreatic water and confined water whose buried depth is less than $50 \mathrm{~m}$ shallow; the bottom boundary depth of second aquifer group is $80-120 \mathrm{~m}$, while the third aquifer group is $150-180 \mathrm{~m}$ and the fourth one is $300 \mathrm{~m}$.

The first phase project of Land Subsidence Monitoring Network and Warning System in Beijing has been built in 2004, three land subsidence monitoring stations were set

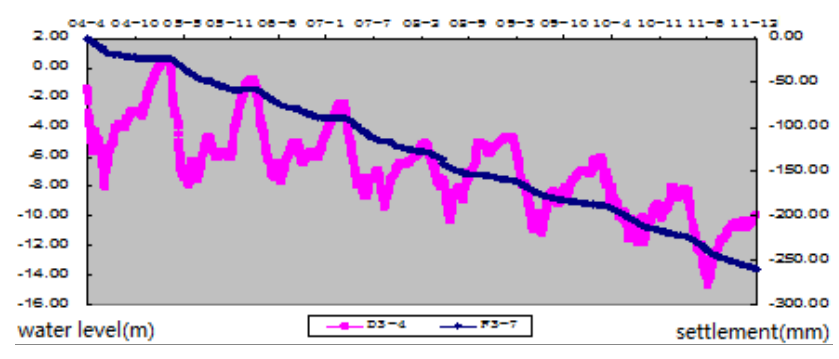

Figure 2. F3-7 (64.5-82.3 m) settlement with the water level elevation of D3-4 in Tianzhu station.

up. There are marked and layered bedrock standard group, groundwater level and pore water pressure monitoring wells in every station (Table 1). Monitoring data of layered water table and settlement in long time series provide a solid basis on the further research between them.

\subsection{Establishment of the regression equation}

For further identification of the intrinsic relationship between the two, multi-linear regression models are set up by long series factual monitoring data about layered water table and settlement in the Tianzhu monitoring station based on quarterly average water table, water level variation and amplitude (Eq. 1).

$y=\beta_{1} x_{1}+\beta_{2} x_{2}+\beta_{3} x_{3}+\varepsilon$

In the equation: $y$ - quarterly accumulated settlement $\left(\mathrm{mm} \mathrm{a}^{-1}\right) ; x_{1}$ - quarterly average water table $(\mathrm{m}) ; x_{2}-$ quarterly water level variation $(\mathrm{m}) ; x_{3}$ - quarterly water level amplitude (m); $\beta_{1}, \beta_{2}, \beta_{3}, \varepsilon-$ the coefficients of regression equation. 
Table 3. The minimum permissible level of groundwater in different control of settlement velocity.

\begin{tabular}{|c|c|c|c|c|c|c|c|}
\hline \multirow{3}{*}{$\begin{array}{l}\text { Monitoring } \\
\text { layer }\end{array}$} & \multicolumn{3}{|c|}{ Control targets (mm) } & \multirow{3}{*}{$\begin{array}{l}\text { Water level } \\
\text { variation } \\
\quad(\mathrm{m})\end{array}$} & \multicolumn{3}{|c|}{ Control targets (mm) } \\
\hline & 45 & 30 & 25 & & 45 & 30 & 25 \\
\hline & \multicolumn{3}{|c|}{$\begin{array}{l}\text { Layered control } \\
\text { targets }(\mathrm{mm})\end{array}$} & & \multicolumn{3}{|c|}{$\begin{array}{c}\text { The minimum permissible } \\
\text { water level }(\mathrm{m})\end{array}$} \\
\hline D3-2/F3-3 & 3.843 & 2.562 & 2.135 & 0.952 & -18.448 & -17.716 & -17.472 \\
\hline D3-3/F3-4 & 4.437 & 2.958 & 2.465 & 2.114 & -16.806 & -16.270 & -16.091 \\
\hline D3-4/F3-6 & 2.705 & 1.803 & 1.503 & 2.081 & -14.502 & -14.021 & -13.861 \\
\hline D3-5/F3-8 & 0.342 & 0.228 & 0.190 & 2.208 & -10.529 & -10.194 & -10.082 \\
\hline
\end{tabular}

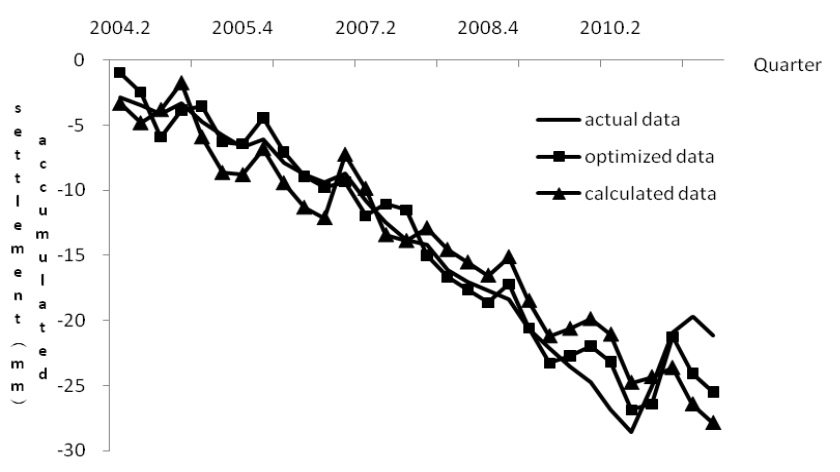

Figure 3. The calculated, actual and optimized value of F3-3.

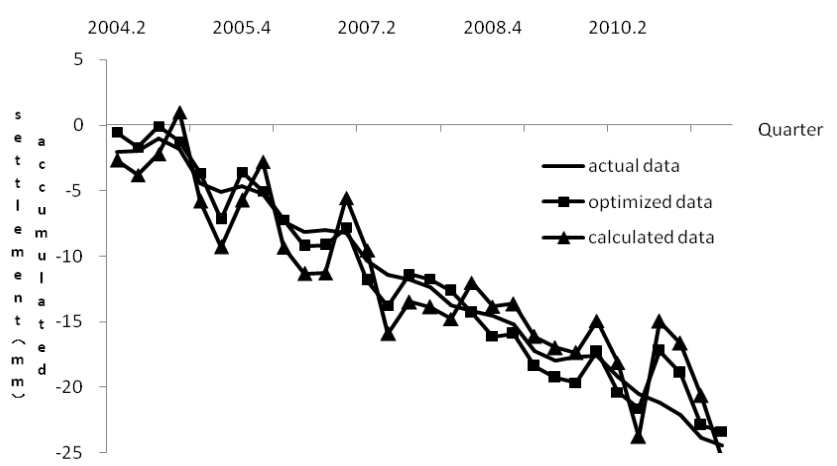

Figure 4. The calculated, actual and optimized value of F3-4.

\subsection{Significant test}

The correlation coefficient of $R$ describes the varying degree of relationship between variable $X$ and $Y$, which can test the significant of the equation. The correlation coefficient is larger, means the sample points are closer to the regression line, the degree of linear correlation is greater (Jia et al., 2003).

The analysis results show that (Table 2), in addition to D3-6/F3-10 monitoring layer, the correlation coefficients of the other layers are greater than 0.8 , the ground ettlement has highly positive correlation with the above factors (Dong, 2006; Hao et al., 2011). F0.05 $(1,28)=4.196$, so that at the

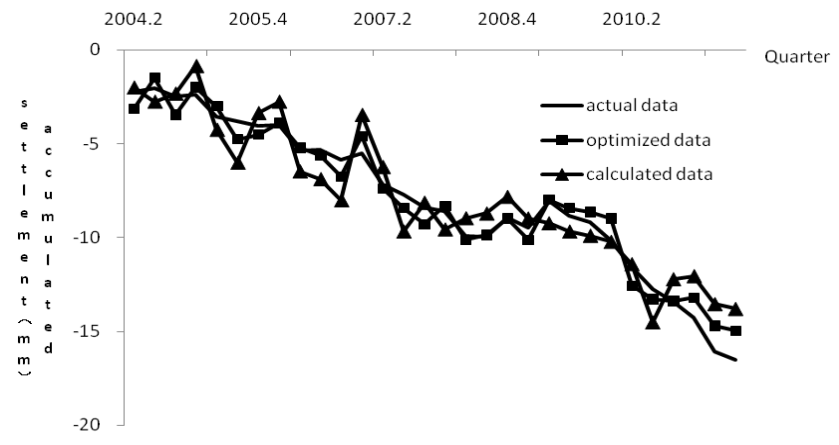

Figure 5. The calculated, actual and optimized value of F3-6.

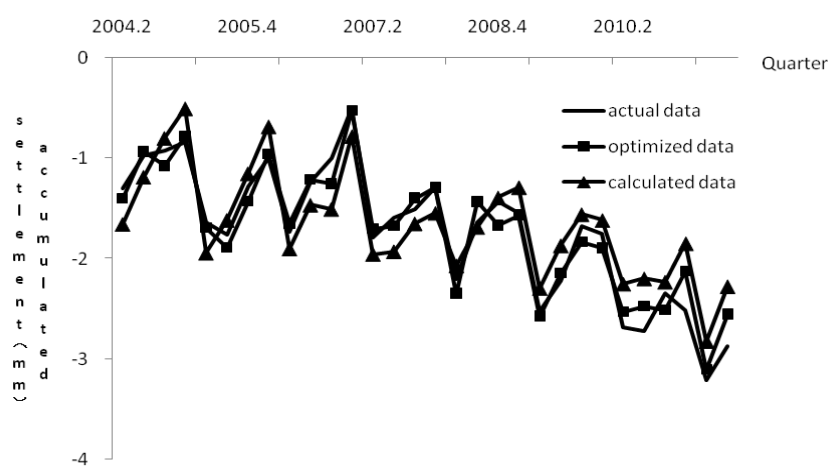

Figure 6. The calculated, actual and optimized value of F3-8.

significance level of 0.05 , in addition to D3-6/F3-10, the other regression equations are significant and practical.

\subsection{Analysis and optimization of regression equation}

The coefficient of quarterly average water table variable $\beta_{1}$ is positive, means the water level is positively correlated with the accumulated settlement (settlement is negative); The coefficient of quarterly water level variation variable $\beta_{2}$ is positive, means the greater water level decline, the greater the amount the cumulative settlement. In addition, from the coefficient of the regression equation, quarterly average water table has the strongest impact on accumulated settlement (Figs. 3-6). 


\section{Allowable layered water level under the threshold value of land subsidence}

According to the annual control targets of land subsidence in Beijing, the threshold values are set as $45,30,25 \mathrm{~mm}$. The layered control target of F3-3, F3-4, F3-6 and F3-8 are calculeted by the historical data of settlement.The minimum allowable layered water level in this region while settlement achieving the threshold value can be calculated (Table 3 ).

\section{Conclusions}

1. Ground subsidence has high degree correlation with the groundwater level in Beijing plain area. On the plane, the range and distribution of land subsidence and groundwater depression are similar. In vertical, there is good consistency between groundwater level variety and land subsidence trend.

2. The ground settlement has highly positive correlation with the average water table, variation and amplitude. Quarterly average water table has the strongest impact on accumulated settlement.
3. According to the threshold value in the land subsidence prevention and control plan of China $(40,30$, $25 \mathrm{~mm}$ ), the minimum allowable layered water level in this region while settlement achieving the threshold value is calculated between -18.448 and $-10.082 \mathrm{~m}$. The results provide a reasonable and operable control target of groundwater level for rational adjustment of groundwater exploited horizon in the future.

\section{References}

Hao, Y., Xu, J., and Zhang, Y.: Research on Application of settlement monitoring model in the calculation of multi factors based on the city ground, J. Railway Eng. Soc., 3, 20-23, 2011.

Jia, Y., Huang, Z., and Zhang, M.: Application of multiple regression analysis and prediction in ground subsidence with water table, J. Geotech. Invest. Surv., 1, 77-79, 2003.

Dong, F.: Prediction model and application of land subsidence, Tianjin University, Tianjin, 2006.

Yang, Y., Jia, S.-M., and Wang, H.-G.: The development of land subsidence in Beijing Plain, J. Shanghai Geol., 31, 23-28, 2010.

Yang, Y., Zheng, F., and Liu, L.: Study on the correlation between groundwater level and ground subsidence in Beijing plain areas, J. Geotech. Invest. Surv., 8, 44-48, 2013. 